\title{
Intercultural Sensitivity and Communication Competence of Healthcare Professionals in Oral and Dental Health Center: A Case Study in Turkey
}

\author{
Perihan Şenel Tekin \\ PhD, Asst. Prof., Ankara University, \\ Vocational School of Health
}

\section{Abstract}

Oral and dental health services in Turkey is open to international competition and a rapidly growing sector within the scope of health tourism. It is very important to maintain patient satisfaction and patient loyalty in service delivery. It is known that patient and patient relatives care about attitudes and behaviors of health workers and this experience is effective in the choose of physicians or health institutions. The aim of this study is to determine the intercultural sensitivity and communication competencies of employees in a private oral and dental health clinic in Denizli which is one of the most important tourism centers of Turkey. In this study, the Intercultural Sensitivity Scale, in which individuals evaluated themselves, was used to measure intercultural sensitivity. This scale, which was developed by Chen and Starosta (2000) and included five emotional dimensions required to be sensitive to interculturalism, was translated into Turkish by Kurban et al. (2011) and evaluated the psychometric suitability. Communication Competence Scale, which was developed by Wiemann (1977) and translated into Turkish, validity and reliability of the communication competence by Koca and Erigüç (2017) was used. Data were collected online via Google docs during January and February 2019. According to the findings of the study, it was observed that the intercultural sensitivity and communication competencies of the health workers were high and the highest score was the enjoyment of communication dimention $(4.10 \pm 0.74)$ in the scale of intercultural sensitivity and the compliance adequacy dimention $(4.13 \pm 0.97)$ in the communication competence scale.

Keywords: intercultural sensitivity, communication competence, oral and dental health services, healthcare professional, Turkey 


\section{Introduction}

Oral and dental health centres (ODHC) are a specialized health service delivery to patients from different cultures at the national or international level. It is very important to maintain patient satisfaction and patient loyalty for the oral dental health services sector, which is growing rapidly in our country and also opened to international competition within the scope of health tourism. In the context of healthcare, patient satisfaction assessment is highly important to reflect quality care (Levin, 2004). Patient satisfaction with dental care has been widely studied (Armfield, Enkling, Wolf, \& Ramseier, 2014; Hashim, 2005; Luo, Liu, \& Wong, 2018; Murray, Densie, \& Morgan, 2015; Stewart \& Spencer, 2005; Thanveer, Krishnan, \& Hongal, 2010).

The main issues affecting patient satisfaction in this area is the quality of the health service received by the patient. Quality is measured by expertise, the material used, price advantage and value obtained (Jaapar, Musa, Moghavvemi, \& Saub, 2017). Although medical providers may have technical skills to successfully treat patients, intercultural skills are also important in increasing the likelihood of patient satisfaction and compliance (Abbey, 2006; Gibson \& Zhong, 2005; Huckabee \& Matkin, 2012). While the effect of quality on service satisfaction is realized over time, the communication experienced (patient-physician communication) by the patient while receiving health care affects patient satisfaction in a shorter time (Al Balushi, Mei, \& Farella, 2017; Campbell, Roland, \& Buetow, 2000).

Patient and patient relatives care about attitudes and behaviours of physicians and other employees within the scope of patient satisfaction and it is known that these experiences are effective in the selection of physician/health institutions (Campbell \& Tickle, 2013; Campbell et al., 2000; de Bondt \& Zentner, 2007). Therefore, it can be said that the attitudes and communication competencies of the health care workers against the patients and their relatives are effective on the patient satisfaction, and the patient satisfaction is effective in the re-preference of the institution/doctor (de Bondt \& Zentner, 2007). In summary, obtaining the desired patient care results in the health service process is related to the behaviours of the physician, nurse and managers during the communication process.

At this point, we encounter two important concepts in the form of intercultural sensitivity and communication adequacy. Intercultural sensitivity (ICS) is accepting cultural difference as they are (without prejudice and ethnocentrism) and evaluating without judgement as well as approaching with positive attitudes (Bulduk ve ark., 2011; Chen ve Starosta, 2000). ICS is a complex with four main dimensions of knowledge, skills, attitudes and awareness (Byram, 1997; Deardorff, 2006; Fantini, 2009; Wiseman \& Koester, 1993). It allows an individual to communicate and interact with people from different languages and cultures through the use of internal features in different intercultural settings (Byram, 1997; Fantini, 2009). These features are generally the knowledge of himself, knowledge about others, attitude, intercultural 
communication, cognitive skills, and awareness. ICS relates to the cognitive, emotional, and behavioural aspects of the interaction situation, but mainly in the emotional field. In addition, intercultural awareness, which corresponds to the cognitive level, leads to intercultural competence, which in turn points to the behavioural dimensions. As a result, these concepts are closely related, but they are seen as separate concepts (Chen \& Starosta, 1998). Individuals with ICS have a motivating desire and tendency to understand, acknowledge and accept differences. This desire and tendency also bring about positive results from intercultural interactions (Chen, 1997; Chen \& Starosta, 1998).

Cultural competence is seen as a critical factor and a key component in providing effective and culturally sensitive health services to an increasing population, reducing racial and ethnic differences in health care, and improving health service quality, patient satisfaction and health outcomes (Campinha-Bacote, 2002; Campinha-Bacote, 2003; Leininger, 2002; Shen, 2015). Intercultural communication is bound between culture and communication, as culture builds the framework in which communication and behaviour are interpreted (Koester \& Lustig, 2012).

Intercultural sensitivity and communication competence is important not only for the effective interaction of health care providers with patients and their relatives but also for ensuring coordination among employees from different cultures. In addition to being competent in intercultural sensitivity and communication competence in contemporary workplaces, awareness of how important these matters are an important issue. Nowadays, cultural differences are seen as a reserve/resource if they are managed well. Therefore, it can be interpreted as a critical objective for the development of human relations (Hajek \& Giles, 2003; Wiewiora, Trigunarsyah, Murphy, \& Coffey, 2013). Indeed, looking at a holistic view of health care will bring the desired quality of service. For this reason, both the cultural and communication competence of the other employees will have an impact on service quality.

In both respects, cultural sensitivity and communication competence, which should be emphasized in the management of health institutions, are worthy of research and development. Analyzing these two issues and transferring the results to management practices will contribute to the development of the sector.

Ultimately, the integration of intercultural sensitivity and communication competence as a fundamental value in health care sectors will not only prepare staff to interact with international patients competently but will also send a strong message about the commitment of organizations to ensure equal access to all patients.

Especially in terms of quality, equal and acceptable service production, cultural differences need to be closely addressed by managers of health institutions in terms of human resources management (Lawler, Walumbwa, \& Bai, 2008) and patient satisfaction. 
In the literature, the studies investigating the intercultural sensitivity of health professionals are mostly concentrated in the field of nursing (Chae \& Park, 2019; Cruz, Contreras, Lopez, Aqueveque, \& Vitorino, 2018; Flood \& Commendador, 2016; Kozub, 2013; Mesler, 2014; Peek \& Park, 2013; Power et al., 2018; Rew, 2014; Roscigno, 2013; Wang, Xiao, Yan, Wang, \& Yasheng, 2018). The communication competence and intercultural sensitivities of caregivers, a requirement of the patient-centred oral health care approach, have not been extensively studied in this area (de Bondt \& Zentner, 2007). To fill this gap, this research aims to determine the level of intercultural sensitivity and communication competence in the scale of the dentists and other employees as a member of the team producing oral and dental health services according to their own perceptions. It was also aimed to reveal the relationship between these two variables with each other. Consequently, the findings may provide guidance on what communication skills and cultural sensitivity dimension of health care workers are, in particular, in the in-service training planning.

\section{Methods}

This study was designed as cross-sectional and descriptive research. This design was chosen since we aimed to determine the relationship between the intercultural sensitivity and communication competence of employee in the private ODHC in Denizli, Turkey. Denizli, the twenty-first most populous city of Turkey. It is famous for its textile products and the local Denizli cock. Denizli is one of the most important tourism centres of Turkey. Pamukkale is the locomotive engine of Denizli's tourism with about 1.5 million tourists per year. Therefore, from different countries, tourism, education, healthcare and commercial purposes many visitors come to Denizli.

The oral and dental health centre was established in 2005 in this study. The centre does not only serve the people of Denizli, at the same time, but it is also a health facility that serves both domestic and foreign tourists. For this reason, this centre, which serves domestic and foreign patients from different cultures, was chosen as the research universe.

\section{Participants}

This study included the employees (dental, assistant, nurse etc) in the private oral and dental health centre in Denizli, Turkey. The population of the study is 64 people working in this centre. Within the scope of the research, it wasn't chosen a sample and it was desired to reach the whole population but because the questionnaires were filled volunteering, the data could be collected from 34 people. This number constitutes $53.13 \%$ of the universe.

\section{Instrument}

In this study, the Intercultural Sensitivity Scale (ISS), in which individuals evaluated themselves, was used to measure intercultural sensitivity for employees in the ODHC. 
This scale, which was developed by Chen and Starosta (2000) and included five emotional dimensions (interaction engagement-7 items, respect of cultural differences- 6 items, interaction confidence-5 items, interaction enjoyment- 3 items, interaction attentiveness- 3 items) required to be sensitive to interculturalism, was translated into Turkish by Kurban et al. (2011) and evaluated the psychometric suitability. The ISS contains 24 statements on a 5 -point scale $(1=$ completely disagree, $2=$ disagree, $3=$ =neutral, $4=$ =agree, $5=$ completely agree). In the scale, items $2,4,7,9,12,15,18,20$ and 22 are coded in reverse. Cronbach's alpha for the ISS Total was 0.877 , with subscale scores ranging from 0.556 to 0.747 .

Communication Competence Scale (CCS), which was developed by Wiemann (1977) and translated into Turkish, validity and reliability of the communication competence by Koca and Erigüç (2017) was used. The CCS is a self-evaluating scale, the original of which consists of 36 items and 5 dimensions, and the Turkish version consists of 30 items and 8 dimensions. These are social behaviuor competence, individual aspects of communication, empathy competence, compliance adequacy, sensitivity adequacy, communication-promoting competence, human relations and listening adequacy. The CCS contains 30 statements on a 5-point scale (1=completely disagree, $2=$ disagree, $3=$ neutral, $4=$ agree, $5=$ completely agree). In the scale, items 4, 8, 11 and 28 are coded in reverse. Cronbach's alpha for the CCS Total was 0.959 , with subscale scores ranging from 0.502 to 0.928 .

\section{Data Collection}

Data were collected online via google docs during January and February 2019. The researcher introduced the study and sent an email with a link of a questionnaire form to volunteer participants. Participants completed the questionnaires, which took about 15 minutes.

\section{Data Analysis}

The data were statistically analyzed using SPSS version 25.0. Data are described using mean and standard deviation or frequency and percentages. The relationship between intercultural sensitivity and communication competencies were investigated by Pearson correlation analysis. P values were significant at a level of 0.05 in this study.

\section{Ethical Considerations}

The participants' rights were the first priority. Therefore, the participants were given written information about research and their right to refuse to participate or withdraw at any point. Completing the questionnaires voluntary was considered as informed consent. The anonymity of the participants was ensured by not collecting any personal identifiers. 


\section{Findings}

The mean age of the participants was $29.21 \pm 7.60$ and the mean of work time was $4.82 \pm 4.29$ years. According to the descriptive findings of the participants, $79.4 \%$ were female; $64.7 \%$ were single; $32.4 \%$ were associate graduated, $26.5 \%$ were dentist and $44.1 \%$ were medical assistant; $61.8 \%$ of the participants do not speak and understand any foreign language; $75.3 \%$ lived in a metropolitan and $88.2 \%$ worked with people from different cultures; $94.1 \%$ did not travel to another country (Table 1).

Table1. Descriptive statistics of the participants

\begin{tabular}{|c|c|c|}
\hline Characteristics & \multicolumn{2}{|l|}{$\chi \pm S D$} \\
\hline Age & \multicolumn{2}{|l|}{$29.21 \pm 7.60$} \\
\hline \multirow[t]{2}{*}{$\begin{array}{l}\text { How long have you been worked in } \\
\text { this hospital? }\end{array}$} & \multicolumn{2}{|l|}{$4.82 \pm 4.29$} \\
\hline & $\mathrm{N}$ & $\%$ \\
\hline \multicolumn{3}{|l|}{ Gender } \\
\hline Male & 7 & 20.6 \\
\hline Female & 27 & 79.4 \\
\hline \multicolumn{3}{|l|}{ Marital Status } \\
\hline Married & 12 & 35.3 \\
\hline Single & 22 & 64.7 \\
\hline \multicolumn{3}{|l|}{ Graduate } \\
\hline High school & 7 & 20.6 \\
\hline Associate Degree & 11 & 32.4 \\
\hline Bachelor & 8 & 23.5 \\
\hline Postgraduate & 8 & 23.5 \\
\hline \multicolumn{3}{|l|}{ Occupation/profession } \\
\hline Dentist & 9 & 26.5 \\
\hline Nurse & 3 & 8.8 \\
\hline Medical assistant & 15 & 44.1 \\
\hline Manager & 1 & 2.9 \\
\hline Others & 5 & 14.7 \\
\hline \multicolumn{3}{|c|}{ The place where you've been living the longest. } \\
\hline Metropolitan & 25 & 73.5 \\
\hline Rural & 8 & 23.5 \\
\hline Foreign country & 1 & 2.9 \\
\hline \multicolumn{3}{|c|}{ Being together with individuals from different cultures. } \\
\hline Yes & 30 & 88.2 \\
\hline No & 4 & 11.8 \\
\hline \multicolumn{3}{|l|}{ Foreign language } \\
\hline Yes & 13 & 38.2 \\
\hline No & 21 & 61.8 \\
\hline \multicolumn{3}{|c|}{ Have you ever been abroad before for tourism, education or working? } \\
\hline Yes & 2 & 5.9 \\
\hline No & 32 & 94.1 \\
\hline
\end{tabular}




\section{Total}

34

100

According to the responses of the participants to the scale of intercultural sensitivity, the mean of the total for the scale was $3.89 \pm 0.52$. When examined in terms of subdimensions, it was seen that the highest average was "enjoyment of communication" with $4,10 \pm 0,74$. The lowest average was observed as "self-confidence in communication" with $3.68 \pm 0.71$ (Table 2).

Table 2. Mean scores on each dimension of ISS

\begin{tabular}{lllll}
\hline Dimentions & $v$ & SD & Min & Max \\
\hline Communication responsibility & 3.84 & 0.58 & 1.71 & 5.00 \\
Respect for cultural differences & 4.06 & 0.63 & 2.50 & 5.00 \\
Self-confidence in communication & 3.68 & 0.71 & 1.40 & 4.80 \\
Enjoyment of communication & 4.10 & 0.74 & 2.67 & 5.00 \\
To be careful in communication & 3.83 & 0.73 & 2.00 & 5.00 \\
\hline Total & 3.89 & 0.52 & 2.21 & 4.67 \\
\hline
\end{tabular}

The values of total and sub-dimensions obtained from the responses of the participants to the communication adequacy scale are given in Table 3. Accordingly, the total communication adequacy score of the participants was 3,82 $\pm 0,58$ and it was high. When it is examined in terms of subscales, it was seen that the lowest average is the dimension which in "human relations dimension" with 3,37 $\pm 0,89$. The highest mean was "the compliance adequacy dimension" with 4,13 $\pm 0,97$.

Table 3. Mean scores on each dimension of CCS

\begin{tabular}{|c|c|c|c|c|}
\hline Dimentions & $\gamma$ & SD & Min & Max \\
\hline Social behaviour competence & 3.85 & 0.65 & 1.50 & 5.00 \\
\hline Individual aspects of communication & 3.99 & 0.64 & 1.33 & 5.00 \\
\hline Empathy competence & 3.87 & 0.72 & 1.00 & 5.00 \\
\hline Compliance adequacy & 4.13 & 0.97 & 1.00 & 5.00 \\
\hline Sensitivity adequacy & 3.85 & 0.73 & 1.00 & 5.00 \\
\hline Communication-promoting competence & 3.65 & 0.82 & 2.00 & 5.00 \\
\hline Human relations & 3.37 & 0.89 & 2.00 & 5.00 \\
\hline Listening adequacy & 3.71 & 0.80 & 2.33 & 5.00 \\
\hline Total & 3.82 & 0.58 & 1.63 & 4.87 \\
\hline
\end{tabular}

The relationship between intercultural sensitivity and communication competence were examined by correlation analysis. As a result of these analyses, a statistically 
significant and positive relationship was found between communication competence and intercultural sensitivity $(\mathrm{r}=0.647 ; \mathrm{p} \leq 0.05)$.

Table 4. Correlation between communication competence and intercultural sensitivity

\begin{tabular}{|c|c|c|c|}
\hline \multirow[b]{2}{*}{ Variables } & \multicolumn{3}{|l|}{ Correlations } \\
\hline & & $\begin{array}{l}\text { Communication } \\
\text { Competence }\end{array}$ & $\begin{array}{l}\text { Intercultural } \\
\text { Sensitivity }\end{array}$ \\
\hline \multirow{3}{*}{$\begin{array}{l}\text { Communication } \\
\text { Competence }\end{array}$} & $\begin{array}{l}\text { Pearson } \\
\text { Correlation }\end{array}$ & 1 & $.647^{* *}$ \\
\hline & Sig. (2-tailed) & & .000 \\
\hline & $\mathrm{N}$ & 34 & 34 \\
\hline \multirow{3}{*}{$\begin{array}{l}\text { Intercultural } \\
\text { Sensitivity }\end{array}$} & $\begin{array}{l}\text { Pearson } \\
\text { Correlation }\end{array}$ & $.647^{* *}$ & 1 \\
\hline & Sig. (2-tailed) & .000 & \\
\hline & $\mathrm{N}$ & 34 & 34 \\
\hline
\end{tabular}

** Correlation is significant at the 0.01 level (2-tailed).

\section{Discussion and Conclusion}

In this research, intercultural sensitivity and communication competencies of a private oral health centre staff serving in Denizli, Turkey were examined. According to the results of this study, intercultural sensitivity and communication competencies of the employees are above average. Compared with a similar study conducted with students of communication faculties in Turkey (Bekiroglu \& Balci, 2014) our findings have similarities with these results. Our intercultural sensitivity findings show that when compared with another study in Turkey, while the employees' cultural sensitivity is similar with nursing and medical students (Bulduk, Usta, \& Yeliz, 2017; Meydanlioglu, Arikan, \& Gozum, 2015).

In this study, which we conducted in a small group and only a single health facility, we could not investigate the factors affecting intercultural sensitivity and communication adequacy. In this study, age, gender, marital status, foreign language knowledge, place of residence and interaction with different cultures are presented as descriptive findings. However, there are studies investigating the relationship between intercultural sensitivity and communication adequacy with these variables.

Many researchers have identified bilingualism or second language skills as an important aspect of intercultural communication competence (Gibson \& Zhong, 2005; Repo et al., 2017). Studies show that knowledge of a foreign language increases intercultural experience and intercultural experience has also shown that it leads to an increase in the knowledge of other cultures that cause individuals to communicate more effectively among cultures (Repo et al., 2017). According to Gibson and Zhong (2005), multicultural and multilingual staff can be more effective in terms of intercultural communication. In this study, only $38.2 \%$ of participants know a foreign 
language and $88,2 \%$ of the population has been together with individuals from different cultures.

In our study, a statistically significant relationship was found between communication competence and intercultural sensitivity. In a similar study, Ulrey and Amason (2001) found a significant relationship between effective intercultural communication and cultural sensitivity (Ulrey \& Amason, 2001). The dissemination of communication competence research into the health service environment is of great importance. Health care is a field of communication research where ineffective communication can have tragic consequences for all participants (Gibson \& Zhong, 2005). In a study conducted on 1191 patients in the United States, it was concluded that there was a positive relationship between the cultural sensitivity of the front office staff and the patient's compliance with the treatment, and increased the patient's health satisfaction level (Wall et al., 2013).

As a result, it is important to understand and improve the communication competence and intercultural sensitivity levels of health workers in the dental care sector. Considering the effect of employees on improving the quality of oral and dental health services, it is important to have an adequate level of intercultural sensitivity and communication adequacy. The training of health professionals can play an important role in increasing this competence.

\section{Limitations}

Data obtained from this study are based on self-report of participants from a small group and only one institution in the study sample and the obtained results cannot be generalized outside of the sample. Given the limitations of this study, results must be viewed with a degree of caution.

\section{References}

[1] Abbey, J. H. (2006). The impact of education and experience on physician assistant students' perception of cultural awareness, knowledge and skills. Journal of allied health, 35(1), 24E-36E.

[2] Al Balushi, S., Mei, L., \& Farella, M. (2017). Patient's satisfaction with orthodontic care from an academic clinical service. New Zealand Dental Journal, 113(4).

[3] Armfield, J. M., Enkling, N., Wolf, C. A., \& Ramseier, C. A. (2014). Dental fear and satisfaction with dental services in Switzerland. Journal of public health dentistry, 74(1), 57-63.

[4] Bekiroğlu, O., \& Balcı, Ş. (2014). Kültürlerarası iletişim duyarlılığının izlerini aramak: "iletişim fakültesi öğrencileri örneğinde bir araştırma", Selçuk Üniversitesi Türkiyat Araştırmaları Dergisi, 35.

[5] Bulduk, S., Tosun, A., Ardıç, E. (2011). Türkçe kültürlerarası duyarlılık ölçeğinin hemşirelik öğrencilerinde ölçümsel özellikleri. Turkiye Klinikleri Journal of Medical Ethics, 19(1):25-31. 
[6] Bulduk, S., Usta, E., \& Yeliz, D. (2017). Kültürlerarası Duyarlılık ve Etkileyen Faktörlerin Belirlenmesi: Bir Sağlık Hizmetleri Meslek Yüksekokulu Örneği. Düzce Üniversitesi Sağllk Bilimleri Enstitüsü Dergisi, 7(2), 73-77.

[7] Byram, M. (1997). Teaching and assessing intercultural communicative competence: Multilingual Matters.

[8] Campbell, S., \& Tickle, M. (2013). What is quality primary dental care? British dental journal, 215(3), 135.

[9] Campbell, S. M., Roland, M. O., \& Buetow, S. A. (2000). Defining quality of care. Social Science \& Medicine, 51(11), 1611-1625.

[10] Campinha-Bacote, J. (2002). The process of cultural competence in the delivery of healthcare services: A model of care. Journal of transcultural nursing, 13(3), 181-184.

[11] Campinha-Bacote, J. (2003). Cultural desire: The key to unlocking cultural competence. Journal of Nursing education, 42(6), 239-240. Retrieved from $<$ Go to ISI $>$ ://WOS:000183404000001.

[12] Chae, D., \& Park, Y. (2019). Organisational cultural competence needed to care for foreign patients: A focus on nursing management. Journal of Nursing Management, 27(1), 197-206. Retrieved from <Go to ISI>://WOS:000456288800024.

[13] Chen, G.-M. (1997). A Review of the Concept of Intercultural Sensitivity.

[14] Chen, G.-M., \& Starosta, W. (1998). A review of the concept of intercultural awareness.

[15] Chen, G.-M., \& Starosta, W. J. (2000). The development and validation of the intercultural sensitivity scale.

[16] Cruz, J. P., Contreras, F. A. M., Lopez, J. E. O., Aqueveque, C. A. Z., \& Vitorino, L. M. (2018). Psychometric assessment of the cultural capacity scale Spanish version in Chilean nursing students. International Nursing Review, 65(2), 262-269. Retrieved from <Go to ISI >://WOS:000434119500018.

[17] de Bondt, B., \& Zentner, A. (2007). Quality management in orthodontic practice. Paper presented at the Seminars in orthodontics.

[18] Deardorff, D. K. (2006). Assessing intercultural competence in study abroad students. Languages for intercultural communication and education, 12, 232.

[19] Koca, G. Ş., \& Erigüç, G. (2017). İletişim yeterlilik ölçeği'nin geçerlik ve güvenilirliği. Uluslararası Yönetim İktisat ve İşletme Dergisi, 13(4), 789-799.

[20] Fantini, A. E. (2009). Assessing intercultural competence. The SAGE handbook of intercultural competence, 456-476.

[21] Flood, J. L., \& Commendador, K. A. (2016). Undergraduate nursing students and cross-cultural care: A program evaluation. Nurse Education Today, 36, 190-194. Retrieved from <Go to ISI >://WOS:000367117000032.

[22] Gibson, D., \& Zhong, M. (2005). Intercultural communication competence in the healthcare context. International Journal of Intercultural Relations, 29(5), 621-634. 
[23] Hajek, C., \& Giles, H. (2003). New directions in intercultural communication competence: The process model. Handbook of communication and social interaction skills, 935-957.

[24] Hashim, R. (2005). Patient satisfaction with dental services at Ajman University, United Arab Emirates.

[25] Huckabee, M. J., \& Matkin, G. S. (2012). Examining intercultural sensitivity and competency of physician assistant students. Journal of allied health, 41(3), $55 \mathrm{E}-61 \mathrm{E}$.

[26] Jaapar, M., Musa, G., Moghavvemi, S., \& Saub, R. (2017). Dental tourism: Examining tourist profiles, motivation and satisfaction. Tourism Management, 61, 538-552.

[27] Koester, J., \& Lustig, M. (2012). Intercultural competence: Interpersonal communication across cultures: Pearson Prentice Hall.

[28] Kozub, M. L. (2013). Through the Eyes of the Other: Using Event Analysis to Build Cultural Competence. Journal of transcultural nursing, 24(3), 313-318. Retrieved from < Go to ISI >://WOS:000320367700011.

[29] Lawler, J. J., Walumbwa, F. O., \& Bai, B. (2008). National culture and cultural effects. Handbook of research in international human resource management, 5-28.

[30] Leininger, M. (2002). Culture care theory: A major contribution to advance transcultural nursing knowledge and practices. Journal of transcultural nursing, 13(3), 189-192.

[31] Levin, R. (2004). The correlation between dental practice management and clinical excellence. Journal of the American Dental Association (1939), 135(3), 345-346.

[32] Luo, J. Y. N., Liu, P. P., \& Wong, M. C. M. (2018). Patients' satisfaction with dental care: a qualitative study to develop a satisfaction instrument. BMC oral health, 18(1), 15.

[33] Meydanlioglu, A., Arikan, F., \& Gozum, S. (2015). Cultural sensitivity levels of university students receiving education in health disciplines. Advances in Health Sciences Education, 20(5), 1195-1204.

[34] Mesler, D. M. (2014). A Comparative Study of Cultural Competence Curricula in Baccalaureate Nursing Programs. Nurse Educator, 39(4), 193-198. Retrieved from < Go to ISI>://WOS:000338508100011.

[35] Murray, C., Densie, I. K., \& Morgan, C. (2015). Dental attendance, perceptions of cost and self-care of school year 12 and 13 students: A focus on Southland, New Zealand. New Zealand Dental Journal, 111(4), 133-141.

[36] Peek, E. H., \& Park, C. S. (2013). Effects of a Multicultural Education Program on the Cultural Competence, Empathy and Self-efficacy of Nursing Students. Journal of Korean Academy of Nursing, 43(5), 690-696. Retrieved from $<$ Go to ISI>://WOS:000327913200012.

[37] Power, T., Virdun, C., Gorman, E., Doab, A., Smith, R., Phillips, A., \& Gray, J. (2018). Ensuring Indigenous cultural respect in Australian undergraduate 
nursing students. Higher Education Research \& Development, 37(4), 837-851. Retrieved from < Go to ISI $>$ ://WOS:000435349700012.

[38] Repo, H., Vahlberg, T., Salminen, L., Papadopoulos, I., \& Leino-Kilpi, H. (2017). The cultural competence of graduating nursing students. Journal of transcultural nursing, 28(1), 98-107.

[39] Rew, L. (2014). The influence of culture on nursing practice and research. Journal for Specialists in Pediatric Nursing, 19(1), 1-2. Retrieved from $<$ Go to ISI $>$ ://WOS:000329370300001.

[40] Roscigno, C. I. (2013). Challenging Nurses' Cultural Competence of Disability to Improve Interpersonal Interactions. Journal of Neuroscience Nursing, 45(1), 21-37. Retrieved from <Go to ISI>://WOS:000313108300006.

[41] Shen, Z. (2015). Cultural competence models and cultural competence assessment instruments in nursing: a literature review. Journal of transcultural nursing, 26(3), 308-321.

[42] Stewart, J. F., \& Spencer, A. J. (2005). Dental satisfaction survey. Dental statistics and Research unit 2005.

[43] Thanveer, K., Krishnan, A., \& Hongal, S. (2010). Treatment satisfaction among patients attending a private dental school in Vadodara, India. J Int Oral Health, 2(4), 33-44.

[44] Ulrey, K. L., \& Amason, P. (2001). Intercultural communication between patients and health care providers: An exploration of intercultural communication effectiveness, cultural sensitivity, stress, and anxiety. Journal of health communication, 13(4), 449-463.

[45] Wall, W., Tucker, C. M., Roncoroni, J., Allan, B. A., \& Nguyen, P. (2013). Patients' perceived cultural sensitivity of health care office staff and its association with patients' health care satisfaction and treatment adherence. Journal of health care for the poor and underserved, 24(4), 1586-1598.

[46] Wang, Y. R., Xiao, L. D., Yan, P., Wang, Y., \& Yasheng, A. (2018). Nursing students' cultural competence in caring for older people in a multicultural and developing region. Nurse Education Today, 70, 47-53. Retrieved from $<$ Go to ISI>://WOS:000445986500008.

[47] Wiemann, J. M. (1977). Explication and test of a model of communicative competence. Human communication research, 3(3), 195-213

[48] Wiewiora, A., Trigunarsyah, B., Murphy, G., \& Coffey, V. (2013). Organizational culture and willingness to share knowledge: A competing values perspective in Australian context. International Journal of Project Management, 31(8), 1163-1174.

[49] Wiseman, R. L., \& Koester, J. (1993). Intercultural communication competence: Sage Newbury Park, CA. 